\title{
Актуальні питання діагностики та лікування кишкової непрохідності, зумовленої комбінованим лікуванням, у хворих зі злоякісними новоутвореннями органів черевної порожнини
}

\author{
M. M. STETS \\ National Medical University by O. O. Bohomolets
}

\author{
ACTUAL ISSUES OF DIAGNOSTICS AND TREATMENT OF INTESTINAL OBSTRUCTION, CAUSED \\ BY COMBINED TREATMENT IN PATIENTS WITH MALIGNANT NEW FORMATION OF ABDOMINAL \\ CAVITY ORGANS
}

\begin{abstract}
За період з 2010-2014 рр. на базі кафедри загальної хірургії № 2 Національного медичного університету імені О. О. Богомольця - Київській міській клінічній лікарні № 3 було обстежено та проліковано 17 хворих із явищами кишкової непрохідності різного генезу, яким попередньо було проведено комбіноване лікування з приводу онкологічної патології органів черевної порожнини. У 5 пацієнтів були явища декомпенсованої непрохідності кишечнику, які ліквідувати консервативними методами не вдалося. Це зумовило проведення ургентних операційних втручань, було діагностовано злукову хворобу черевної порожнини, хворим було виконано вісцероліз із наступною назогастроінтестинальною інтубацією кишечнику. Летальність у даній групі була відсутня. У 12 пацієнтів, на тлі ефективності проведення консервативних заходів лікування, операційні втручання було проведено в терміни від 3 до 5 діб. Серед зазначеної групи пацієнтів 3 хворим було виконано накладання обхідних анастомозів, 7 пацієнтам здійснено ілеостомію, а в 2 випадках моносигмостомію. Летальність у даній групі склала 2 (12 \%) пацієнти. Методом вибору хірургічної тактики у хворих із канцероматозом черевної порожнини є паліативні втручання, що покращують якість життя цієї тяжкої категорії хворих.

Over the period 2010-2014, at the Department of General Surgery №2 of National Medical University named after O. O. Bohomolets - Kyiv City Clinical Hospital №3 were examined and treated 17 patients with symptoms of intestinal obstruction of various origins, which had previously been carried out combination therapy for cancer pathology of the abdominal cavity. 5 patients had decompensated bowel obstruction phenomenon that failed to eliminate conservative methods. This led to conduct urgent surgeries, was diagnosed abdominal adhesive disease, they were satisfied viscerolisis nasogastrointestinal followed by incubation of the intestine. Mortality in this group was absent. In 12 patients, on the background of the effectiveness of the treatment of conservative measures, surgical interventions were carried out in a period of 3 to 5 days. Among this group of patients was performed in 3 patients imposition of bypasses, 7 patients ileostomy was performed, and in 2 cases monosigmoidostomy. Mortality in this group was $2(12 \%)$ patients. The method of choice of surgical tactics in patients with abdominal carcinomatosis is a palliative intervention, improving the quality of life of patients with this severe category.
\end{abstract}

Постановка проблеми і аналіз останніх досліджень та публікацій. Суспільно-політичний стан України у 2014-2015 рр. спричинив труднощі отримання повної інформації про рівень ураження населення всієї території країни злоякісними новоутвореннями. За уточненими даними Національного канцер-реєстру України (НКР), у 2013 р. було зареєстровано 164465 нових випадків захворювання на злоякісні новоутворення (3Н); загальний грубий показник захворюваності на ЗН досяг 384,9 на 100 тис. населення, тобто порівняно 32012 р. достовірно збільшився на 1,2 \%, у т. ч. у жіночого населення на 1,5 \%, у чоловічого - на 0,6 \%.

Порівняно з 2012 р. зростання стандартизованого показника захворюваності чоловічого населен- ня в 2013 р. було зареєстровано при ЗН глотки, підшлункової залози, нирки, передміхурової залози, при злоякісній меланомі шкіри та множинній мієломі і зменшення цього показника при ЗН шлунка, гортані та кісток. У жіночого населення рівень захворюваності зріс при ЗН тіла матки, глотки, гортані, щитоподібної залози та немеланомних ЗН шкіри.

Кількість померлих від раку в 2013 р. складала 80520 осіб, при цьому грубий показник смертності дорівнював 188,4 на 100 тис. населення, що на 2,1 \% нижче, ніж у попередньому році. При дослідженні вікової структури захворілого та померлого від ЗН населення України встановлено, що в 2013 р. 40,0 \% захворілих і 39,2 \% померлих чоловіків складали особи працездатного віку, а серед жінок - 26,6 
і 18,9 \% відповідно, тобто зазначені особливості онкоепідеміологічного процесу беззаперечно суттєво впливали як на трудовий, так і на репродуктивний потенціал нації.

У структурі смертності від ЗН чоловічого населення перші п’ять рангових місць у 2013 р. посіли ЗН легені, шлунка, передміхурової залози, колоректальний рак (55,0 \%); у жінок - ЗН молочної залози, шлунка, колоректальний рак і рак яєчника (50,5 \%).

За інформацією Національного канцер-реєстру в 2014 р., на профілактичних оглядах було виявлено 29,8 \% онкологічних хворих. Малоефективним було виявлення на профілактичних оглядах пухлин прямої кишки: цю патологію було активно виявлено у 22,3 \% випадків.

Показник морфологічної верифікації діагнозу захворювання на ЗН у 2014 р. в цілому в Україні дорівнював 83,8 \%. Високий рівень морфологічного підтвердження мали пухлини візуальних локалізацій (понад 95 \%) та гемобластози (до 100 \%). Розподіл усіх виявлених у 2014 р. в Україні нових випадків захворювання на ЗН за стадіями (згідно з класифікаціями Анн-Арбор та TNM діючого у регіонах перегляду) показав, що 52,8 \% 3 них були виявлені у 1-2-й стадії розвитку пухлини, 17,5 \% - у 3-й стадії і 14,9 \% - у 4-й стадії. Вивчення онкоепідеміологічної ситуації в Україні показало, що рівень захворюваності населення на ЗН у 2013 р. порівняно з 2012 р. зріс.

Особливої уваги заслуговує категорія онкологічних хворих, у яких післяопераційний період супроводжується специфічністю проявів після комбінованого лікування, з ускладненнями якого переважно стикаються лікарі загального та хірургічного профілю. Останні, як правило, перебувають у соціально скрутних ситуаціях із надання допомоги даній категорії хворих і виконання симптоматичних паліативних операційних втручань, які супроводжуються незадовільними результатами. Відсутність літературних даних про досвід лікування цієї тяжкої категорії хворих зумовила мету нашої роботи.

Мета роботи: вивчити особливості діагностики та лікування кишкової непрохідності, зумовленої комбінованим лікуванням, у хворих зі злоякісними новоутвореннями органів черевної порожнини.

Матеріали і методи. За період 2010-2014 pp. на базі кафедри загальної хірургії № 2 Національного медичного університету імені О. О. Богомольця - Київській міській клінічній лікарні № 3 було обстежено та проліковано 17 хворих із явищами кишкової непрохідності різного генезу, яким попередньо було проведено комбіноване лікування з приводу онкологічної патології органів черевної порожнини. Усі хворі були госпіталізовані в ургентному порядку. 3 них 5 оперовані екстрено, а 12 - у відстроченому періоді. Вік хворих складав від 45 до 70 років. Чоловіків було 3, а жінок - 14. У структурі ЗН жінок переважали новоутворення органів малої миски, а у чоловіків - колоректальний рак.

Особливістю даної категорії хворих є проходження курсів ПХТ та променевої терапії, що проявлялося вираженою кахексією, анемією, гіпопротеїнемією, явищами хронічної гепаторенальної недостатності та водно-електролітних розладів. При цьому в основному маніфестація явищ кишкової непрохідності відбувалась поступово, крім випадків гострої странгуляційної непрохідності. Визначальним діагностичним методом у комплексному моніторингу була оглядова рентгенографія органів черевної порожнини в поєднанні з УЗД. У категорії хворих із частковою кишковою непрохідністю обов'язковим був рентгеноконтроль пасажу барію по ШКТ.

Ступінь тяжкості хворих визначався усіма критеріями шкали АРАCHЕ II, а віковий критерій доповнював синдром взаємообтяження. Таким чином, у 12 пацієнтів був тяжким, що відповідав оцінці - 21 за шкалою АРАСНЕ II, а у 5 хворих вкрай тяжким, що відповідав оцінці - 14 за шкалою АРАСНЕ II. Операційно-анестезіологічний ризик за шкалою ASA відповідав III-IV-E класу.

У всіх хворих відразу після госпіталізації лікування починалося із заходів, спрямованих на відновлення водно-електролітного балансу, корекцію функції серцево-судинної системи, декомпресію проксимальних відділів шлунково-кишкового тракту та спроб консервативними заходами і малоінвазивними методиками перевести декомпенсовану непрохідність у субкомпенсовану. Останні включали в себе проведення спазмолітичної терапії, постановку сифонних клізм, постановку перидурального катетера, а також обов'язкове проведення фіброколоноскопії. Зазначена діагностична процедура давала можливість не лише верифікувати рівень, характер перешкоди, ступінь звуження просвіту кишки, а й визначитися $з$ можливим варіантом проведення доопераційної декомпресії товстої кишки, що було пріоритетною метою всієї передопераційної підготовки.

Результати досліджень та їх обговорення. Незважаючи на обсяг проведених лікувальних заходів, у 5 пацієнтів явища декомпенсованої непрохідності кишечнику ліквідувати не вдалося. Це зумовило проведення ургентних операційних втручань у терміни від 2 до 8 год перебування хворих у 
стаціонарі, що, безумовно, знайшло своє відображення у об'ємі останніх. У всіх хворих було діагностовано злукову хворобу черевної порожнини. Так, їм було виконано вісцероліз із наступною назогастроінтестинальною інтубацією кишечнику. Летальність у даній групі була відсутня.

У 12 пацієнтів, на тлі ефективності проведення консервативних заходів лікування, операційні втручання були виконані в терміни від 3 до 5 діб, що дозволило здійснити корекцію гіповолемії і наявної супутньої патології та провести адекватну декомпресію кишечнику. Серед зазначеної групи пацієнтів 3 хворим було виконано паліативне хірургічне лікування - накладання обхідних анастомозів, 7 пацієнтам було проведено ілеостомію у зв'язку з вираженим канцероматозом черевної порожнини, а в 2 випадках моносигмостомію в зв'язку із зазначеним процесом миски малого та-

\section{СПИСОК ЛІТЕРАТУРИ}

1. Бондарев В. И. Комплексное хирургическое лечение острой спаечной непроходимости кишечника / В. И. Бондарев, Р. В. Бондарев, А. А. Орехов // Харківська хірургічна школа. - 2009. - № 2.2 (34). - С. 133-136.

2. Бюлетень національного канцер-реєстру України (2015). - К., 2015. - Вид. № 16.

3. Гобеджишвили В. К. Прогнозирование и профилактика развития спаечного процесса у больных, оперированных на органах брюшной полости / В. К. Гобеджишвили, М. П. Лаврешин, Р. К. Гезгиева // Анналы хирургии. - 2006. - № 3. С. 42-45.

4. Гордійчук П. І. Кишкова непрохідність пухлинного генезу як проблема невідкладної хірургії (патогенез, діагностика, клініка, лікування, хірургічна реабілітація : автореф. дис. на здобуття наукового ступеня доктора медичних наук. 14.01.03 / П. І. Гордійчук. - К. : Інститут хірургії та трансплантології, 2002. - 31 с. за. Летальність у даній групі склала 2 (12 \%) пацієнти. Основною причиною незадовільних результатів лікування було прогресування поліорганної недостатності на фоні інтоксикаційного синдрому та ракової хвороби.

Висновки. 1. Тяжкість даної категорії хворих потребує комбінованої інтенсивної підготовки для створення сприятливих умов виконання хірургічного втручання.

2. В однієї третини пацієнтів явища кишкової непрохідності були зумовлені злуковим процесом черевної порожнини, а в більшої частини - прогресуванням метабластичного процесу.

3. Методом вибору хірургічної тактики у хворих із канцероматозом черевної порожнини є паліативні втручання, що покращують якість життя цієї тяжкої категорії хворих.

5. Дикий О. Г. Сучасні аспекти лікування спайкової хвороби очеревини / О. Г. Дикий // Клінічна хірургія. - 2008. № 4-5. - С. 14.

6. Корымасов Е. А. Принципы дифференциальной диагностики и тактики при острой кишечной непроходимости / Е. А. Корымасов, Ю. В. Горбунов // Вестн. хирургии им. И. И. Грекова. - 2003. - № 3. - С. 10-106.

7. Раззадорин С. С. Оказание хирургической помощи больным с кишечной непроходимостью опухолевого генеза / С. С. Раззадорин, А. С. Сыкал, Ю. Л. Шальков : материалы Междунар. хир. конгресса “Актуальные проблемы современной хирургии”, 22-25 февраля 2003 г., Москва. - М., 2003. C. 121.

8. Руководство по неотложной хирургии органов брюшной полости / под ред. В. С. Савельева. - М. : Медицина, 1976. 497 c.

Отримано 21.07.15 